\title{
Desen Eğitiminde Edebiyatın Rolü: Kafka ve Wells Örneği
}

\author{
Öğr. Gör. Dr. Mehtap Pazarlıŏlu Bingöl
}

\section{Öz}

1960'lardan günümüze sanata, sanatçıya ve sanat yapıtına karşı algılar değişmiş, kavramsal sanat, performans sanatı, vücut sanatı, video sanatı gibi disiplinlerarası özellikler taşıyan sayısız sanat hareketi, sanat eğitimi sürecini de yeniden değerlendirme zorunluluğu getirmiştir. Bu anlamda çalışmada, desen eğitiminde disiplinlerarası bir yaklaşım olarak desen-edebiyat ilişkisi irdelenmektedir. Desen eğitiminde edebiyatın rolü, Gazi Üniversitesi Güzel Sanatlar Fakültesi Görsel İletişim Tasarımı Bölümü I. Sınıf öğrencilerinin Desen dersi final projeleri olarak hazırlanan bir uygulama örneği ile ortaya koyulmaya çalışılmıştır. Çalışma, desen dersinin disiplinlerarasılık bağlamında yeniden ele alınması gerekliliğine vurgu yapmaktadır.

Anahtar Kelimeler: Disiplinlerarası, Edebiyat, Desen

\section{THE ROLE OF LITERATURE IN DRAWING EDUCATION: KAFKA AND WELLS EXAMPLE}

\begin{abstract}
Since 1960's various artistic trends bearing interdisciplinary features such as conceptual art, performance art, body art and video art have appeared. With these trends, perceptions toward the artist and the art work have also started to change, and inevitably, arts education has been subjected to these changes as well. In this study, the relationship between drawing and literature was addressed in the context of interdisciplinary approach. The role of literature in drawing education was examined with a final project assigned to the freshman students taking drawing course at Gazi University Fine Arts Faculty Visual Communication Design Department. The result of the study shows that drawing course need to be revisited in terms of interdisciplinarity.
\end{abstract}

Keywords: Interdisciplinarity, Literature, Drawing 


\section{Giriş}

20. yüzyılda ortaya çıkan sanat akım ve hareketlerinde farklı disiplinlerin birlikteliği gözlenebilir. Yirminci yüzyıldan günümüze uzanan sanat evreninde, video, hareket-dans, müzik, edebiyat ve resim gibi alanlar bir arada yer alabilmekte, böylelikle yeni bir sanatsal ifade biçimi kendini göstermektedir. Sanat dalları arasındaki sınırların esnemesi ve/veya bu sınırların daha geçirgen bir yapıya bürünmesi, sanat eğitiminde bu yapıyla uyumlu bir düzenlemeye gidilme gereğini akla getirmektedir.

Ülkemizdeki sanat kurumları da çağın gerekliliklerini göz önünde bulundurarak disiplinlerarası geçişi öne çıkaran etkinliklerde bulunmakta ve farklı alanların birlikteliğinin tecrübe edilebileceği eğitim-öğretim süreçlerine yer vermektedir. Çok alanlı bir zeminde gerçekleşen sanat eğitimiyle, öğrencilerde dünyada olanlarla ilgili bir bilgi birikimi oluşurken, öğrenciler bu yeni ve deneysel çalışmalarla da özgün ifade biçimlerine ulaşabilirler. Çağdaş sanat eğitimcisi, eğitim-öğretim sürecine güncel sanat olaylarını konu etmeli ve öğrencileri ile birlikte çağını anlamaya çalışarak, bu disiplinlerarası yaklaşımları ele almalıdır. Malzeme kullanımlarındaki geniş olanaklar, farklı disiplinlerin birlikteliğinde ortaya çıkarılan yeni sanatsal ifadeler, ister istemez sanat eğitimi sürecinde de bu tür arayışları gündeme getirmektedir.

Çağdaş sanat eğitiminin, yeni sanat hareketlerinden haberdar olan, çeşitli yapıdaki sanat olaylarını yorumlayabilen, geçmişteki sanat eserleri ile günümüz sanat çalışmalarını bağlamlarında değerlendirebilen akademisyen ve sanat öğrencilerine ihtiyacı vardır. Sanat eğitimcileri, çağına uygun eğitim yaklaşımlarını ders programları için önerebilmelidir. Görsel sanatlarda özgün eserlere ulaşabilmek için tekrarlardan uzaklaşarak, disiplinlerarası bir yaklaşımla, içinde bulunulan çağdaki yeniliklerin farkında olunması gereklidir. Bu nedenledir ki desen eğitiminde geçmişin birikimlerinden beslenen, bugünün olanakları ile yeni ifade biçimlerine ulaşmayı hedefleyen biçimselliğin ötesinde düşünsel bir temelde varlığını gösteren bir yaklaşım sergilenebilir. Bu çalışma, desen eğitimi sürecine edebiyatı katarak disiplinlerarası bir yaklaşım önermektedir.

\section{Desen Eğitimi}

Desen, plastik sanatların temelini oluşturan bir disiplin ve yüzyıllardır kendi başına sanat eseri olabilme özelliğini de gösteren bir alandır. Desenin ana karakteri olan çizgi, kalınlığı, inceliği, kesik, kırık, uzun, kısa oluşu ve farklı yönlerde bulunma biçimi ile etkili bir anlatım aracıdır (Bingöl ve Kayahan, 2015: 223). Çizginin gücünü ortaya koyacak olan desen çalışmaları ile 
sanat öğrencileri ya da sanatçılar bilinçli bir şekilde gördüklerini herhangi bir yüzey üzerine aktarabilirlerken, duygu ve düşüncelerini de bu yolla ifade edebilmektedirler. Desen, zihinsel bir süreç gerektirdiği gibi aynı zamanda ruhsal bir etkinliktir.

Desen eğitimi ile öncelikle alana dair araç ve gereçleri kullanma becerisi kazanan öğrenci, özgür ve özgün denemeler gerçekleştirir. Karşısındaki figürü/objeyi algılayarak, ona dair zihninde bilgiler oluşturur. Kendisinin rahatıkla tanımlayabildiği obje ya da figüre ait bilgileri çizgileri ile bir başkasına anlatabilir. Üç boyutlu varlıkların hacimsel özelliklerini çizgi ve lekesel değerleri kullanarak iki boyutlu bir yüzeye aktarabilir. Desen eğitimi sürecinde ayrıntılar çok büyük önem taşımaktadır. Öğrenci bu ayrıntıları keşfederken sorgulamayı öğrenir. "Sanat insanın kendini tanımasına, yaşamı ve var oluş nedenini sorgulamasına, sonu ve sonsuzluğu kavramasına fırsatlar yaratan bir eylemdir. Bu nedenledir ki sanatçılar için yaşam, doğum ve ölüm tarihleri arasına sıkışıp kalmış bir kısa çizgi değildir. Yaşam sonsuzluktur, ölümsüzlüktür" (Pekmezci, 2002: 37).

Desen eğitimi yoluyla birey, gözlem yapmayı, araştırmayı, sorgulamayı, yaratıcı ve ıraksak düşünmeyi öğrenir. Karşılaştığı sorunlara farklı bakış açıları ile yaklaşarak çok boyutlu çözümler üretebilir. Desen eğitimi sürecinde objelerin kendi içlerinde ya da birbirleriyle ilişkilerindeki oran ve orantıyı kavrayan öğrenci gözlem yapma, araştırma alışkanlıkları kazanır, çevresindeki olaylara-olgulara dikkati yoğunlaşır. Bu doğrultuda olaylar arasındaki bağlantıları değerlendirip, özgürce kararlar verebilir. Bu sebepledesen eğitimi de diğer alanlarda olduğu gibi, teknolojik gelişmelere ayak uydurabilmeli, en azından sanat alanında yaşanan değişim ve dönüşümlerden haberdar bir şekilde kendini güncelleyebilmelidir.

\section{Disiplinlerarası Sanat}

Disiplinlerarası sanat, içerisinde fonetik çıkış noktaları olan ve teatral görselliği de beraberinde taşıyan bir olgudur. Bundan dolayıdır ki bir sanat yapıtını anlamlandırabilmek için onu bütüncül olarak ele almak gerekmektedir. Artık resimsel dille, şiirsel dil ayrımı ortadan kalkmış, var olan sanatsal disiplinlere eklenen yeni disiplinlerle sanatın boyutları genişlemiştir (Başar, akt: Heptunalı, 2007: 33).

1960 ve 70'lerde ortaya çıkan Eylemler (Actions), Yoksul Sanat (Arte Pouera), Vücut Sanatı (Body Art), Kavramsal Sanat (Conceptual Art), Yeryüzü Sanatı (Earth Art), Fluxus, Oluşumlar (Happenings), Gösteri Sanatı (Performance Art), Süreç Sanatı (Process Art) gibi sanat eğilimleri farklı disiplinleri bir araya getirerek, gelecekte var olacak sanat çalışmalara yeni bir soluk getirmişler, bu anlamda disiplinlerarası 
Disiplinlerarası çalışmalar, sanat ve bilim alanlarında sınırları genişleterek, bu alanlara farklı bakış açıları ve çözüm önerileri sunan yeni bir perspektif getirmiştir.P. Klee'ye görehızla değişen dünyadasanatın görevigörünmeyeni görülür kılmak, gerçeklerin ifadesini bulacağı yeni biçimler oluşturmaktı. Sanatın bu görevi, farklı sanat alanlarını birbirine oldukça yaklaştırmıştı (Erdal, 2009: 147). İçinde bulunduğumuz elektronik çağda bilgisayar teknolojisinden uzak kalmak imkansızdır. Hem görsel hem de işitsel verilerin depolanmasında ve yeniden işlenmesinde kullanılan bilgisayarların, sanatta da kullanılması kaçınılmazdır. 1967 yılında Nam June Paik'in Charlotte Moorman ile beraber gerçekleştirdikleri seri çalışmalar, video sanatına örnek teşkil etmektedir. Onların sunumlarında video monitörleri, maddi bir kazanç olarak değil, bir aracın farklı kullanımlarının denemeleridir. Paik, televizyonu bozmuş, içini pislikle doldurarak simgesel olarak dışkı boşaltmış, içine bitkiler yerleştirerek, doğal zamanı göstermek istemiş, televizyonu bir mobilyaya dönüştürerek ise mimarlıkla, iç dekorasyonla olan yakınlığını vurgulayarak disiplinlerarası ilişkileri gözler önüne sermiştir. Vito Acconci, 1971 yılında Centers (Merkezler) adlı çalışmasında kendi bedenini görüntünün malzemesi olarak kullanarak vücut sanatını elektronik ortamda gerçekleştiren eleştirel bir yaklaşım ortaya koymuştur (Altunay, 2004: 161-175).

Alman sanatçı Joseph Beuys'un (1921-1986), 1965 yılında yaptığı “i iki Saplı Bel" 'de kalp biçimindeki bıçak sevgiyi, iki sap ise kanın aktığı şah damar ile atar damarı simgelemektedir. 24 saat süren eylem boyunca beli kalbinin hizasında tutmuş, belli aralıklarla başının üzerine kaldırarak, yere vurup, atarak gösteriye ses öğesini de eklemiş, ses, gürültü, tınıların da kullanıldığı süreçte çalışmayı farklı disiplinlerin bir arada kullanıldığı bir uygulamaya dönüştürmüştür (Atakan, 1998: 33). Kosuth 1985 tarihli "Sıfır ve Değil (Zero \& Not) adlı çalışmasında, galeri yüzeylerini Freud'un "The Psychopathology of Everyday Life" (Günlük Yaşamın Psikopatolojisi) adlı kitabından aldığı bir paragrafın büyütülerek basılan 31 kopyasıyla kaplamıştır. Bu paragraf Freud'un "Slip of the Pen" (Kalem Sürçmesi) başlıklı bölümünden alınmıştır. Freud, yayıncısından aldığı hatalı bir telgraftan söz ederek, kitapta bilinçaltı arzuların sonucu olarak farkında olmadan yaptığı yazım yanlışlarını incelemiştir. Kosuth ise sanatçı ile yapıt, yapıt ile izleyici arasındaki süreci yansıtırken, yapıtın sergilendiğinde sanatçının bilinçaltı sürçmelerini gösterdiği gibi yorumları da beraberinde getirmektedir. Kosuth'un birçok yapıtına gönderme yapan kelimeler, Freud'un Interpretation of Dreams (Rüyalar ve Yorumları) adlı kitabındaki satırların farklı anlamlara dönüştürülmesiyle oluşmaktadır (Atakan, 1998: 
86-87).

Kosuth'un 1965 yılında gerçekleştirdiği çalışması olan "Bir ve Üç Sandalye"de, ortada bir sandalye, solunda aynı sandalyenin fotoğrafı ve sağında da nesne olarak sandalyenin sözlük tanımı yer almaktadır. Yerleştirmede sanatçı, nesne, nesnenin görüntüsü ve sözcük tanımları arasındaki ilişkinin irdelenmesini istemektedir (Yılmaz, 2005: 226). Anselm Kiefer, "Baş Rahibe" adlı yapıtında Tarot kartlarına bir gönderme yapmaktadır. Büyük sırların ikincisinin adı 'Başrahibe' ve Bilgiyi temsil etmektedir. Çelik raflardaki kurşun kaplı büyük boyutlu kitaplar insanlığın başarılarını simgelemektedir. Sanatçı, çalışmasında bilginin gücünü ve değerini ifade ederken aynı zamanda ondan yararlanmanın zorluklarını da belirtmektedir (Lynton, 2004: 354). 1960'lardan günümüze sanat artık, bir satın alma ya da salt estetik haz uyandıran bir nesne değildir. Sanat, farklı disiplinlerin birlikteliğinde yeni yaklaşımların sergilendiği, toplumların birbirleriyle iletişimlerinin sağlandığı bir süreçte varlığını sergilemektedir. "

Disiplinlerarası sanat ve teknolojinin sanata yansıması üzerine yaşanan gelişmeler tüm dünyada olduğu gibi Türkiye'de de hissedilmektedir. "İstanbul Bienali" ile birlikte Türkiye'de disiplinlerarası sanat kavramı, izleyicilere aktarılmıs, ardından genç sanatçılardan oluşan bir grup 1996 yılında Disiplinlerarası Genç Sanatçılar Derneği'ni kurmuşlardır. Söylemlerini izleyiciler ile buluşturabilmek için performans günleri düzenlemişlerdir. Ülkemizde zamanla, çeşitli devlet kurumları ve özel galeriler de para amacı taşımaksızın sanat hareketlerinin gelişimini desteklemek için girişimlerde bulunmuşlardır. 2005 yılında Dokuz Eylül Üniversitesi'nde ilki düzenlenen "Görsel Sanatlar Buluşması"nda teknolojik gelişmelerle birlikte sanattaki yeni oluşumları izleyicilerle buluşturan bir dizi etkinlik gerçekleştirilmeye başlamıştır. Ardından Üniversitelerde "iletişim Tasarımı" ve "Multimedya" bölümlerinin açılmaları ve çalışmaları teknolojiyi sanata dahil etme anlamında önemli gelişmelerden sayılabilir (Heptunalı, 2007: 94-95).

Günümüzde yazılı metin, ses ve video kayıtları ile gerçekleştirilen geniş bir sanatsal üretim ağı bulunmaktadır. Beliz Demircioğlu Cihandide Intouch adlı videosunda, izleyiciler görüntülere dokunduklarında, bir süre sonra ekranda Tanzanyalı ve Ganalı çocuklar görünmektedir. Sanatçı, Afrika'daki elverişsiz yaşam koşullarında yaşayan çocuklara ilgi ve destek göstermenin gerekliliğine vurgu yapmaktadır (Türkdoğan, 2014: 268269). Disiplinlerarası program için prensipler, estetik ilkelerin kullanımı, geniş üretici temalar, bir veya birden fazla disiplin için standartlar, diğer disiplinlerde anahtar kavram ve ilkeler ve paylaşılan unsur, işlev veya durumlar içermektedir (Suraco, 2006: 15). Farklı disiplinlerin birbirleri ile 
etkileşiminin eğitim sistemi, özelde sanat eğitimi ve öğrencileri üzerine katkıları olacaktır. Disiplinlerarası yaklaşım, öğrencinin gelecekteki öğrenmesine temel teşkil edecek olan yaşam boyu öğrenme becerileri yönünde pek çok fayda sağlayacaktır (Jones, 2009: 76).

\section{Sanat Disiplinleri Arasındaki Etkileşim: Edebiyat}

Sanat dalları arasındaki rol, birbirlerine kaynak oluşturarak güçlenmektir. Sanatlar arasında estetik bir ilişki bulunmaktadır ve görsel sanatların karakterlerinin bir metinde yer alışı, romana kapsamlı ve zengin yeni bir yön ilave eder. Yazarlar, ressamları çalışmalarında yaratıcı süreçlerin nasıl geliştiğini ve hayal güçlerinin nasıl esere dönüştüğünü ilham kaynağı olarak kullanarak dikkatli bir şekilde resimleri açımlandırabilmektedirler (Meyers, 1975: 1-2). Edebiyat ve resim ilişkisi düşünüldüğünde ressamların edebiyatçılardan, yazarların ya da şairlerin de ressamlardan etkilendiği bir alan belirmektedir. Bir edebiyat metninde yer alan ilk minyatür örneklerinden biri, iki genç arasındaki aşkı anlatan Varka ve Gülşah mesnevisidir. 11. yy. şairi Ayyuki tarafından yazıımış Gazneli Sultan Mahmud'a sunulmuş ve Hay'dan Konya'ya göç etmiş bir aileden gelen ressam Abdülmümin b. Muhammed tarafından çeşitli sahnelere ayrılan 71 resimle resimlendirilmiştir. Hz. Hüseyin'in Kerbela'da şehit edilmesini konu alan makteller de resimle edebiyatı bir araya getiren eserlerdendir. Örneğin; Türk edebiyatında divan şairi Fuzûli'nin Hadikatü's Süeda (Kutluların Bahçesi) adlı eserinin çok sayıda minyatürlü yazması bulunmaktadır. Aynı zamanda Fuzûli'nin yazdığı Leyla ile Mecnun mesnevisi de, içeriğini görselleştiren minyatürlerle zenginleştirilen edebiyat metinlerindendir (Buğra, 2000: 39-41).

Edebiyatın, diğer sanat dalları ile ilişkisini yalnızca edebi metinlerin görselleştirilmesinde aramamak gerekir. Orhan Pamuk'un "Benim Adım Kırmızı" adlı romanında Minyatür resmini ele aldığı, buradan yola çıkarak, minyatür sanatının tarihsel seyrini ve minyatür sanatçısının kişiliğindeki sanat ve sanatçıya ait meseleleri de ele alarak işlediği anlaşılmaktadır (Buğra, 2000: 118-120). Pamuk, minyatürü, yazısında kullandığı betimlemeler ile tekrar gözler önüne getirmektedir. Bedri Rahmi, resimde şiir ve ışık bütünlüğünü aradığı gibi, şiirinde de resim ve ışık güzelliğini arar. Bedri Rahmi'nin gerek şiirlerinde gerekse resimlerinde tasvir ettiği dış dünya, onun ruh hallerini imajlar ve sembollerle gösterilen unsurların yansımasıdır. Tevfik Fikret, mısralarında ses, söz, resim sanatlarını birleştirmiştir. Pablo Picasso'nun "Guernica" adlı eserinden yola çıkarak "Guernica" adlı şiiri yazan Illhan Berk, şiirinde tıpkı tabloda geçen savaşı, acıları dile getirir (Edebiyat Kalemi, 2013). Edebiyatla-resmin kesiştiği noktada geçmişin 
acıları, bir başka kültürde yinelenmekte ve paylaşılmaktadır. Konak Belediyesi ve Yalınayak Yayınları'nın ortaklaşa düzenlediği, ressam Filiz Kahraman'ın 24 Aralık 2013 tarihinde Alsancak Prof. Dr. Türkan Saylan Kültür Merkezi'nde açılan "Çoban Yıldızı" isimli sergisinde Kahraman, gazeteci-yazar Gökmen Küçüktaşdemir'in sergiyle aynı adı taşıyan romanını görselleştirerek resim çalışmalarını gerçekleştirdiğini dile getirmiştir (Haberler, 2013). Enstalasyon sanatçılarından biri olan Genco Gülan'ın Amerika'da Rice Üniversite'sinde Elektronik Edebiyat dersi çerçevesinde okunulacak yapıtlar listesindeki "Etkileşimli Şiir" $i$ sözcüklerin, görsel bir yapıda yeniden üretimine örnek teşkil etmektedir. Uygulayıcının kelimelere dokunması ile beraber yeni biçimler, oluşumlar gerçekleşmektedir (Graf, 2008'den akt: Sözen, 2010: 154). Yazılan edebi bir metin, sinemaya, tiyatroya, bir heykele, resme uyarlanmaya, aktarılmaya çalışıldığında, eser, hem eseri okuyan, hem onu sanat eserine dönüştüren kişiler tarafından yeniden değerlendirilir. Edebi metin, okuyucusunun bilgi birikimine göre de zenginleşip farklı bir konuma da yerleşebilir. Her ne durumda olursa olsun, ele alınan roman, öykü ya da şiir, başka bir disiplin içerisinde kendini göstermeye başladığında; yeni, yine bir değer kazanacak, yeni oluşan yapıt üzerinden edebi metin tekrar hatırlanacak ve özgün biçimlerde varlığını devam ettirecektir. Avusturyalı roman ve oyun yazarı, şair, denemeci Peter Handke şöyle belirtmektedir:

\footnotetext{
"Bir edebi eserden kendim için bir yenilik beklerim; beni pek az da olsa değiştiren bir şeyler beklerim; bana gerçekliğin henüz düşünülmemiş, henüz bilincine varılmamış bir imkanını fark ettirsin, yeni bir görme, söyleme, düşünme, var olma imkanı ...ve ben kendimin ancak edebiyat sayesinde daha bilinçli yaşayabildiğimi fark ettiğim içinde ki edebiyat sayesinde başkalarını değiştirebileceğimden eminim. Kleist, Flaubert, Dostoyevski, Kafka, Faulkner, Rabbe-Grillet benim dünya bilincimi değiştirmiştir" (Yamaner, 2007: 137).
}

Özdemir Asaf'ın eşi Yıldız Moran ile açtıkları Şiir-Fotoğraf sergisi (1974), Ali Cengizkan'ın Magnum Fotoğraf Alansı'nda çalışan Constantine Manos'un çektiği fotoğraflara şiirler yazması gibi daha birçok örnek ile fotoğraf ve şiir arasındaki disiplinlerarası ilişkiye dikkat çekilebilir (Ak, 2003: 15-16). Aytaç'a göre edebiyat metinleri filme çekilmekte ve yeni işlevsel ve anlamsal bağlamlar kazanmaktadır (Aytaç, 2005: 21). Yazınsal metinler öncelikle görsel sanatlardan Tiyatro, ardından sinema ile görselleştirilmeye başlamıştır. Sinema, başlangıcından itibaren senaryo dışında başka türlerde yazılmış yazınsal metinlere başvurmuştur. Roman, masallar, halk hikayeleri/söylenceleri hem Türk filmlerine hem de diğer yabancı filmlere konu olmuş ve sinemaya uyarlanmıştır. Yazınsal bir yapıt, sinemalaştırılabilir, görsel bir yapıta dönüştürülebilir, bu farklı alanda, 
içerdiği değişiklikler ile ortaya çıkan eser, eski eserden bağımsız, yeni bir eser olma niteliği taşımaktadır (Ünser, 2004: 9-13). Romanlardan sinemaya uyarlanan bazı Türk filmlerine örnek olarak; Burhan Arpad'ın "Alnımdaki Bıçak Yarası" (1987) verilebilir. Rıfat Ilgaz'ın orta öğretim günlerini anlatan romanı (1959) Hababam Sınıfı... Shakespeare eserlerinden Hırçın Kız, Türk sinemasında "Erkek Fatma Evleniyor/PALAY-1965, Yavaş Gel Güzelim/ Ün-1963 filmleri romanlardan uyarlanmış filmlerdir (Ünser, 2004: 122279).

Hollandalı ressam Johannes Vermeer'in "Girl With a Pearl Earring (Inci Küpeli Kız) isimli tablosu onun başyapıtlarındandır. Tracy Chevalier'in romanlaştırdığı İnci Küpeli Kız, 2003 yılında Peter Webber'in yönetmenliğinde, Olivia Hetreed tarafından filme uyarlanmıştır. "The Da Vinci Code (Da Vinci Şifresi)" Dan Brown'un romanından sinemaya uyarlanmıştır. "The Lord of the Rings (Yüzüklerin Efendisi)" J. R. R. Tolkien'in romanından, Peter Jackson'un yönetmenliğinde sinemaya uyarlanmışır. Romanlardan sinemaya uyarlanan daha çok sayıda film bulunmaktadır. Edebi eserler sinemaya uyarlanırken kimi zaman kaynak metne sadık kalınarak görselleştirilmiş, kimi zaman ise romanın konusu ile uyuşmayan yeni öyküler oluşturulmuştur.

Varşova'da Modern Sanatlar Müzesi'nde 26-27 Ekim 2013'de, David Maroto ve Joanna Zielinska küratörlüğünde "The Book Lovers-The Novel as an Art Form" (Kitapseverler- Bir Sanat Biçimi Olarak Roman) başlıklı bir dizi etkinlik gerçekleştirilmiştir. Etkinlikte sanatçılar romanı, sanatsal bir araç olarak kullanmışlardır. Onların yaratıcı stratejileri, sonuçtan ziyade sürece odaklanmakta, görsel sanatlar için kurgu, kişileştirme ve yazarlık konuları gibi öyküsel literatüre özgü yapılar sunmaktadırlar. Çalışmalarda, kişisel kimlik eğilimlerinin ortadan kaldırılması ve yeni öznel değişim alanları yaratılmasına dikkat çekilmektedir. Tarihsel bir bakış açısına göre sanatçının romanı kavramsal sanattan ziyade ilişkisel estetikten türemiş gibidir. Sanatçıların romanlarının görünümleri üzerine gerçekleşen bir araştırma projesi olan "The Book Lovers" da önemli olan soru, bu çalışmada bir romanın görsel sanatlar içinde bir video sanatı ya da enstalasyon olarak nasıl bir araç olabileceğidir (The Book Lovers, 2011). 

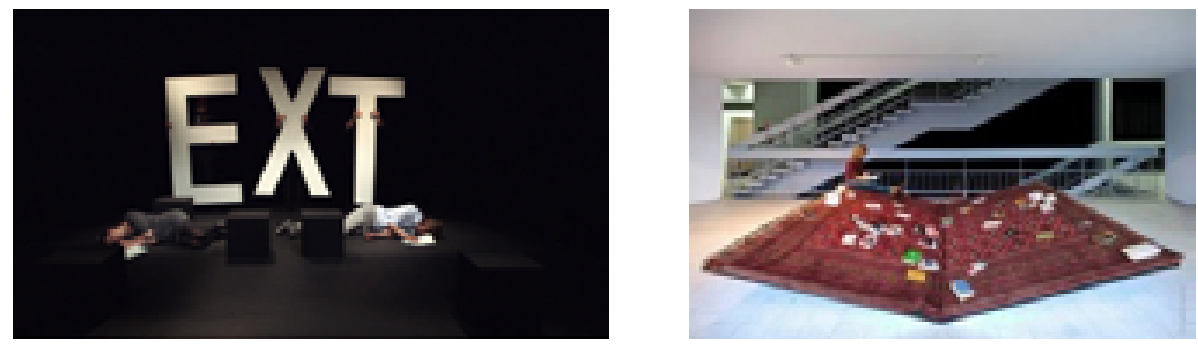

Resim I-2:"The Book Lovers-The Novel as an Art Form" Performance

Edebiyat ve sanatın birleşimi konusunda verilebilecek diğer bir örnek de, 2010 yılında Kayahan tarafından yapılan Hikâye anlatım yönteminin öğrencilerin yaratıcılığı üzerindeki etkilerini araştıran tezdir. Kayahan, bilim kurgu romancılı̆̆ının öncüsü sayılan Fransız yazar Jules Verne'nin“Ay'a Yolculuk" isimli hikâyesini İlköğretim öğrencilerinin yaratıcılıklarına yapacağı etkiyi öğrenmeye yönelik kullanmış ve sonucunda klasik resim derslerinin ötesindeki bu disiplinlerarası yaklaşımın uygulandığı sınıf öğrencilerinin, yaratıcılık düzeylerinde olumlu bir artış olduğunu ortaya koymuştur (Kayahan, 2010).

\section{Desen Eğitiminde Edebiyatın Kullanımına Yönelik Uygulama Örnekleri}

Desen eğitimi, bireysel duyarlıkeğitimidir. Süreçte, öğrenciye, sanatın sosyal, kültürel ve eğitsel işlevinin farkındalığının oluşması amaç edinilmeli, aynı zamanda edebiyat, müzik gibi farklı sanatlardan da zevk alan, bilinçli bir alt yapıya sahip, eleştiri gücü yüksek bireylerin yetiştirilmesi hedeflenmelidir. Günümüzde malzeme olanakları hayal sınırlarının gücünü aşmakta, bu sayede sanatçılar-tasarımcılar malzemenin kendi özelliklerinden de yola çıkarak, çok farklı anlatım biçimlerine ulaşabilmektedirler. Kopyacı bir anlayıştan uzak, öğrencilerin yaratıcılıklarını ortaya çıkaran, bir metni inceleyebilen, tartışabilen gençlerin hayal güçlerini devreye sokan bir desen, atölye ortamında oluşacak eğitim süreci, çok daha anlamlı olacaktır. Bu çalışmanın amacı, görsel sanatlar eğitiminde özel olarak desen eğitimi sürecinde, edebiyat-desen uygulama ilişkilerini disiplinlerarası etkileşim bağlamında irdelemek ve uygulama örnekleri ortaya koymaktır. Edebiyatı da içine alan süreçte desen dersi yapılandırılır ve düşünsel bir yaklaşımla, desen başka bir boyuta taşınır.

Çalışma, 2013-2014, 2014-2015 eğitim-öğretim döneminde, Gazi Üniversitesi Güzel Sanatlar Fakültesi, Görsel Illetişim Tasarımı Bölümü 1.sınıf öğrencileri ile desen dersi kapsamında gerçekleştirilmiştir. Final 
projesine kadar geçen 1 yıllık eğitim-öğretim sürecinde öğrenciler canlı modelden çizimler yapmışlar ve gördüklerini birebir desen kağıdına aktarabildikleri kompozisyonlar çalışmışlardır. Yetenek sınavı ile Fakülte'ye alınan öğrencilerin, gerçekleştirilecek Final Projesi için hazır bulunuşluk düzeyleri yeterli kabul edilmiştir. Süreçte, öğrenciler Kafka'nın "Şato ve Dönüşüm", Wells'in "Zaman Makinesi" romanlarını okumaya teşvik edilmişlerdir. Final projeleri için seçilen bu edebi eserlerin, öğrencilerin hayal güçlerini geliştireceği ve yaratıcı düşünme biçimlerine olumlu katkıda bulunacağı düşünülmüştür.

Edebi bir metni görsele dönüştürürken, sadece metinde yer alan karakterler, mekanlar ya da nesneler onlara ait özellikleri ile resmedilmekle kalmaz aynı zamanda desen çalışmasını yapan öğrenci, kendi yaşamı ile yazarın yaşamını birleştirip, coşkun ve daha duyarlı anlatımlara ulaşabilir. Öğrenci, içsel olarak kimi zaman kendine dahi anlatamadığı saklı boyutlarını gün yüzüne çıkarabilir. Metindeki derin anlamları, bütün boyutlarıyla kavramaya ve romanı oluşturan bütündeki tek tek parçalara ulaşmaya başlar. En azından final projesi için gerçekleştireceği desen çalışması böylesine derin bir kavrama ile daha gerçekçi bir boyuta taşınacak, elde edilen çıktı, hem romanın görsel bir anlatımı hem de öğrencinin derinlerindeki duygularının da bir ifadesi olacaktır.

Gazi Üniversitesi Güzel Sanatlar Fakültesi Görsel İletişim Bölümü "Desen" dersi 1. sınıfın final projesi için öğrencilerden, Kafka'nın "Dönüşüm" ve "Şato", Wells'in "Zaman Makinesi" adlı eserlerini, anlatıların özeti olacak şekilde toplam 10 karede görselleştirmeleri istenmiştir. Elde edilecek çıtı ise minimum $30 \times 40 \mathrm{~cm}$. boyutunda olacaktır. Bu doğrultuda kitapların özetleri atölyede öğrencilerle birlikte okunmuş, yazarların eserleri ve yaşadığı dönemler hakkında tartışmalar gerçekleştirilmiştir. Ardından, öğrencilerden tüm yıl boyunca gerçekleştirilen desen anlayışı doğrultusunda kompozisyonlara ulaşmaları, hedef olarak gösterilmiştir. Öğrencilerin eserler hakkındaki yorumlarını, kendi bakış açılarıyla en iyi şekilde ifade edebilecekleri kompozisyona ulaşabilmeleri için, her türlü tekniği ve dijital teknolojiyi kullanmaları serbest bırakılmıştır. Öğrencilerin her biri, farklı bir edebi eser okuyup, yeni bir dünya keşfetmiştir. Yazarın yaşamı, yaşadığı dönemdeki siyasi-ekonomik koşullar konuşularak, romandaki karakterler ya da mekanlar üzerine değerlendirmeler yapılmıştır. Bir hafta sonra derse okumuş oldukları romanı anlatan eskizleri ile gelen öğrencilerle, çalışmaları hakkında kritikler yapılmıştır. Her bir öğrencinin tek tek çalışmaları, grup içerisinde tartışılmış ve kompozisyonlarına, kullandıkları karakterlere dair yorumlar gerçekleştirilmiştir. Böylelikle çalışmalarını tekrar gözden geçirebilme imkanı bulan gençler, eleştiriler doğrultusunda desenlerinde 
değişiklikler yapıp, çalışmalarını tamamlamışlardır.

Romandaki bir karakter, bir mekan ya da herhangi bir ayrıntı görsel bir öğe olarak çizgisel ifade biçiminde yeni bir düzenlemeye dönüşmüştür. $\mathrm{Bu}$ düzenlemede romanda gerçekleşen olaylar-duygular aktarılmaya çalışıırken, aynı zamanda öğeler arasındaki denge, boşluk-doluluk, küçük-büyük, zıtlık, açık-gri-koyu değer, hareket gibi farklı sanatsal düzenleme öğe ve ilkelerinin de göz önünde bulundurulduğu bir kompozisyon aranmıştır. Romanlarda oluşturulan karakterler, olaylar, olgular, okuyucuya farkı bakış açıları, yaşantılar sunarken bunun yanı sıra okuyucunun kendi yaşamındaki duygu alanlarına dokunabilen hassas dengeleri de bünyesinde barındırır. Her yeni okuyucu ile başka bir boyuta taşınan roman, görsele dönüşürken aslında her yeni görüntü karesi, onu oluşturan kişinin yaşamından parçaları da içermeye başlar. Bu bağlamda proje, Avant-garde'ın söylemlerini araştıran, teknolojinin egemenliğindeki dünyanın tüketim kültürüne hizmet etmeyen, etken pratik bir süreç arayışı işlevini üstlenmektedir. Öğrenciler, yaşamdaki temsilleri sorgulamalı, sanat çalışmalarını çağına, bağlamına göre değerlendirebilmeli, yeni form ve ifade arayışlarına girmeye cesaret edebilmelidirler.

\subsection{Kafka'nın "Metamorphosis (Dönüşüm)" Adlı Eserinin Desen Eğitimi'nde Uygulama Örneği}

Franz Kafka'nın 1912' de yazdığı "Metamorphosis" (Dönüşüm), birçok kısa filme konu olan ve 2012 yllında Chris Swanton'un yönetmenliğinde uzun metrajı bir filme uyarlanan önemli bir edebi eserdir (Wikipedia, 2015). Dönüşüm adlı roman ilk olarak 1915 yılında yayımlanmıştır. Romanda, bir sabah uyandığında kendini dev bir böcek olarak bulan Gregor Samsa'nın hikayesi anlatılmaktadır. Samsa'nın böceğe dönüşmesinin sebepleri romanda geçen diğer karakterlerin çevresinde aranmalıdır. Kafka'nın Dönüşüm'ü onun yabancılaşma kavramını ne denli içten yaşadığının bir göstergesidir. Onun eserinde aile, toplumun bir metaforudur.

Kafka öncelikle kendine, ardından çevresine yabancılaşma durumunu böceğe dönüşerek sanatsal bir anlatımla ifadelendirmiştir (Bingöl ve Taşpınar, 2014: 60). Gelişen teknoloji, insanları birbirlerine yakınlaştırırken, kimi zamanda sosyal medya, ilişkilerde sanal bir gerçeklik yaratıp bireylerin yalnızlaşmalarına sebep olmaktadır. Yabancılaşma olgusu Kafka'nın yaşamından ya da romanlarından çıkıp günümüz insanının günlük hayatında birebir yaşayabileceği bir kavrama dönüşmüştür. Bireyler, sosyal paylaşım ağları sayesinde en keyifli anlarını aynı saniye birçok kişi ile paylaşabilirken, aslında yaşadığı andan koparak, kendilerine sanal ve yapay bir dünya yaratmaktadır. Kişi, bir gün teknolojinin yoğun bir 
şekilde etrafını sarmış olduğu yaşamında yalnızlığını fark ettiğinde, belki de $\mathrm{o}$ an, kendi isteklerinin ne olduğunu dahi tanımlayamayacak kadar yabancılaşma kavramının içinde olacaktır.
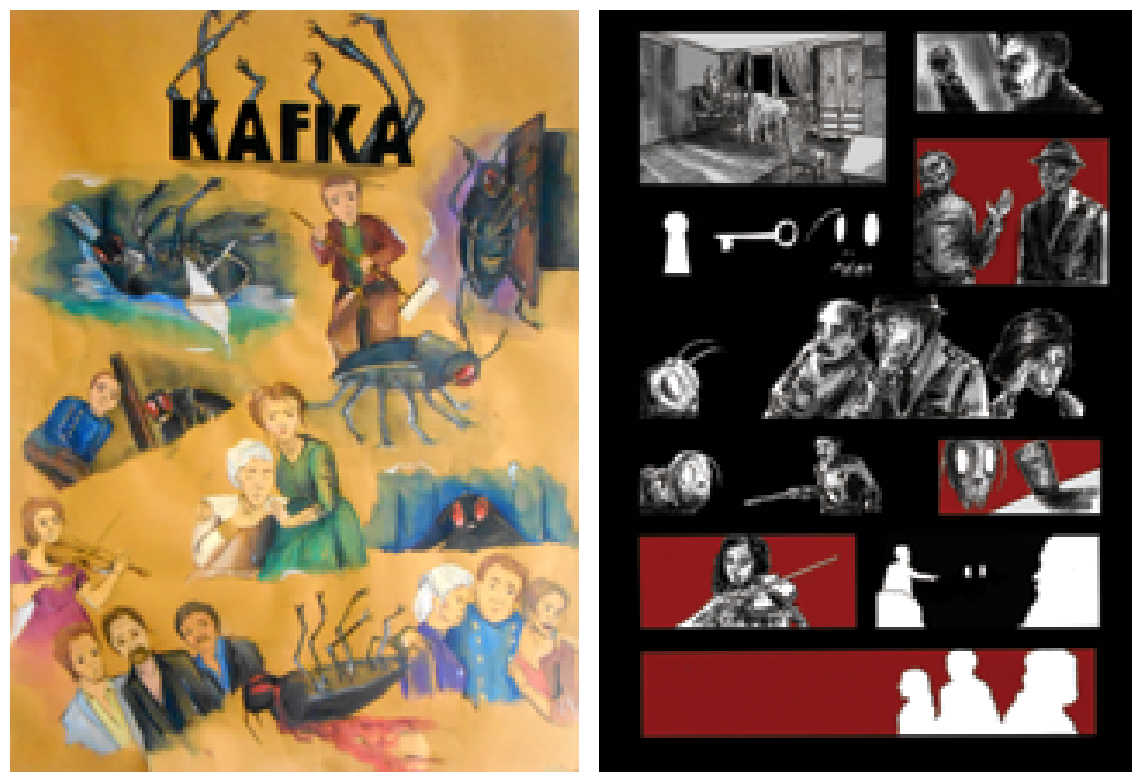

Resim 3: Merve Bayhan, Öğrenci Çalışması Resim 4: Cengiz Dallıkavak,Öğrenci Çalışması
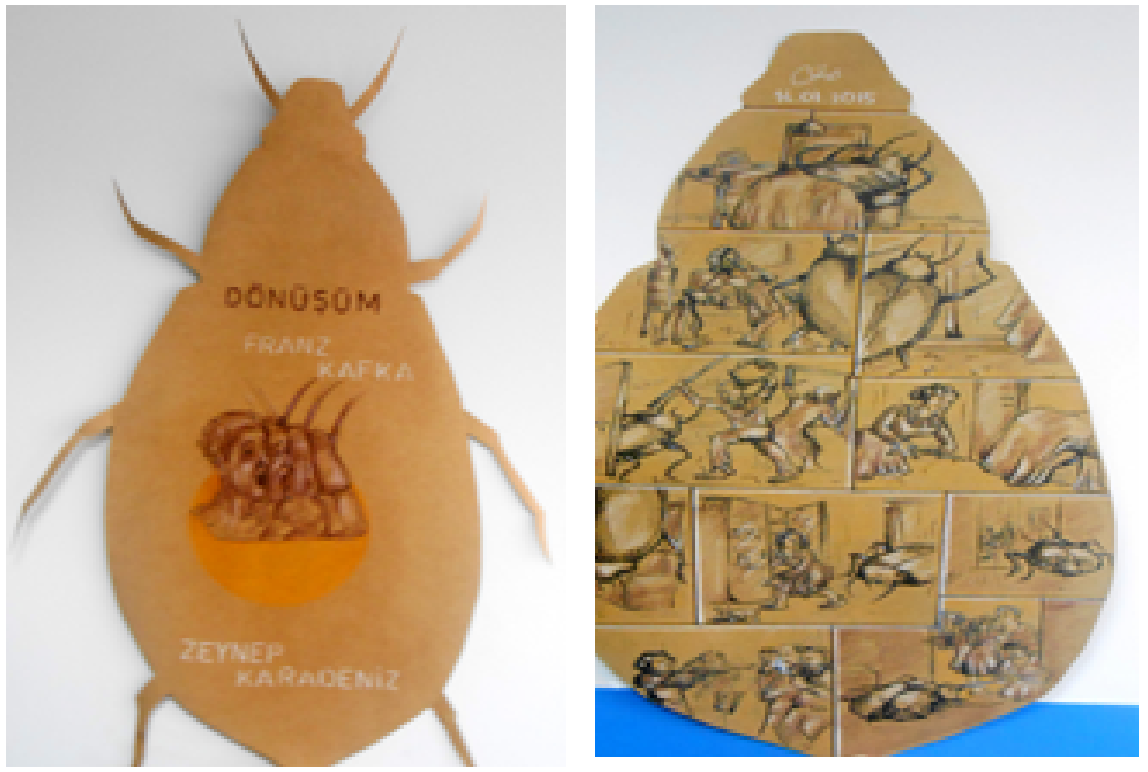

Resim 5: Zeynep Karadeniz, Öğrenci Çalışması 


\subsection{Kafka'nın "Şato" Adlı Eserinin Desen Eğitimi'nde Uygulama Örneği}

Franz Kafka "Şato" adlı eserini 1922 yılında yazmaya başlamıştır. Max Brod, Kafka'nın ölümünden iki yıl sonra 1926 yılında eseri yayımlamıştır. Romanın ana karakteri Kadastrocu K.'dır. K, bir kasabanın şatosunda çalışmaya başlar. Şatoyu temsil eden herhangi bir yetkili ile görüşmek istemesine rağmen, bir türlü kimse ile görüşemeyen K'nın, kasabada yalnız kalışı, bürokrasiye bir türlü ulaşamaması eserin önemli ipuçlarıdır. Kafka'nın eserlerindeki yabancılaşma kavramının gün yüzüne çıkması bu romanında da net bir şekilde görülmektedir. K, kadastrocu olmasına rağmen kasabadan iş yapacağı kendisi tarafından da bilinmemektedir. Yazar, tüm bu bilinmezlik içerisinde romanın kahramanına, yine de Şato'ya giden yolu aratarak içindeki yok olmamış olan "umut" kavramını da okuyucuya aktarmıştır.
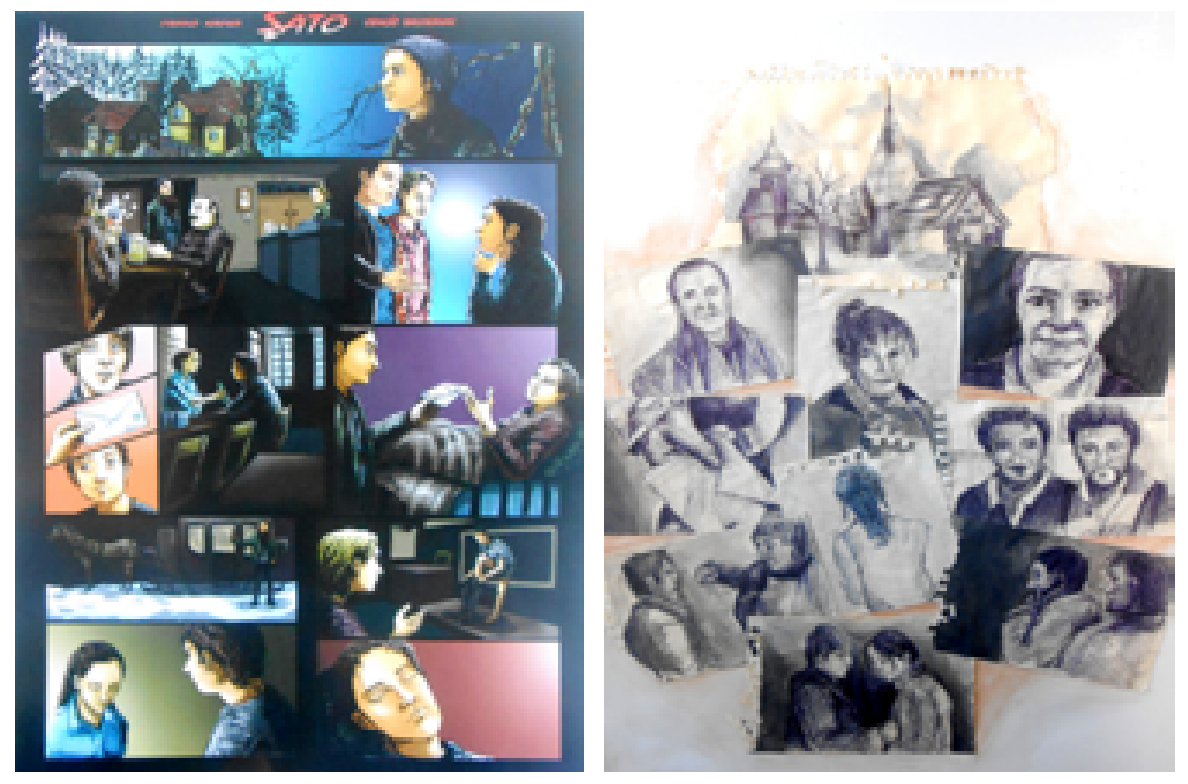

Resim 6: Cengiz Dallıkavak, Öğrenci Çalışması

Resim 7: Merve Bayhan, Öğrenci Çalışması 


\subsection{H. G. Wells'in “The Time Machine (Zaman Makinesi) Adlı Eserinin Desen Eğitiminde Uygulama Örneği}

Herbert George Wells (1866-1946) İngiliz yazar, bilim kurgu dalında çok önemli eserler vermiş̧tir. Eserlerinin çoğunda siyasi ve sosyal içeriklere yer veren Wells, gelecekteki teknoloji olanaklarını hayal ettirip, olası teknoloji ürünlerine yönelik düşünceler geliştirmiş̧ir. H. G. Wells'in 1895 yılında yayımlanan "The Time Machine (Zaman Makinesi)" bir bilim kurgu kitabı olma özelliği ile başyapıtları arasında yer almaktadır (Wikipedia, 2015). Bir bilim adamının İngiltere' deki evinde misafirlerini ağırlarken, kendi icadı olan zaman makinesi ile yaptığı yolculuğu anlatan "Zaman Makinesi", sinemaya da uyarlanan edebi bir metindir. İcadı olan araç ile geleceğe yolculuk yapan ana kahraman, farklı bir insanlık tarihi ile karşılaşmaktadır. Bilim kurgu alanında zamanının en yaratıcı çalışmalarından olan yapıt ile öğrenciler, hayal gücünün önemini kavrarlar. Hayal gücü, bilimsel, sanatsal ve teknolojik olarak insanlığı ileri götürecek gelişmeleri olanaklı kılan bir yetenektir.
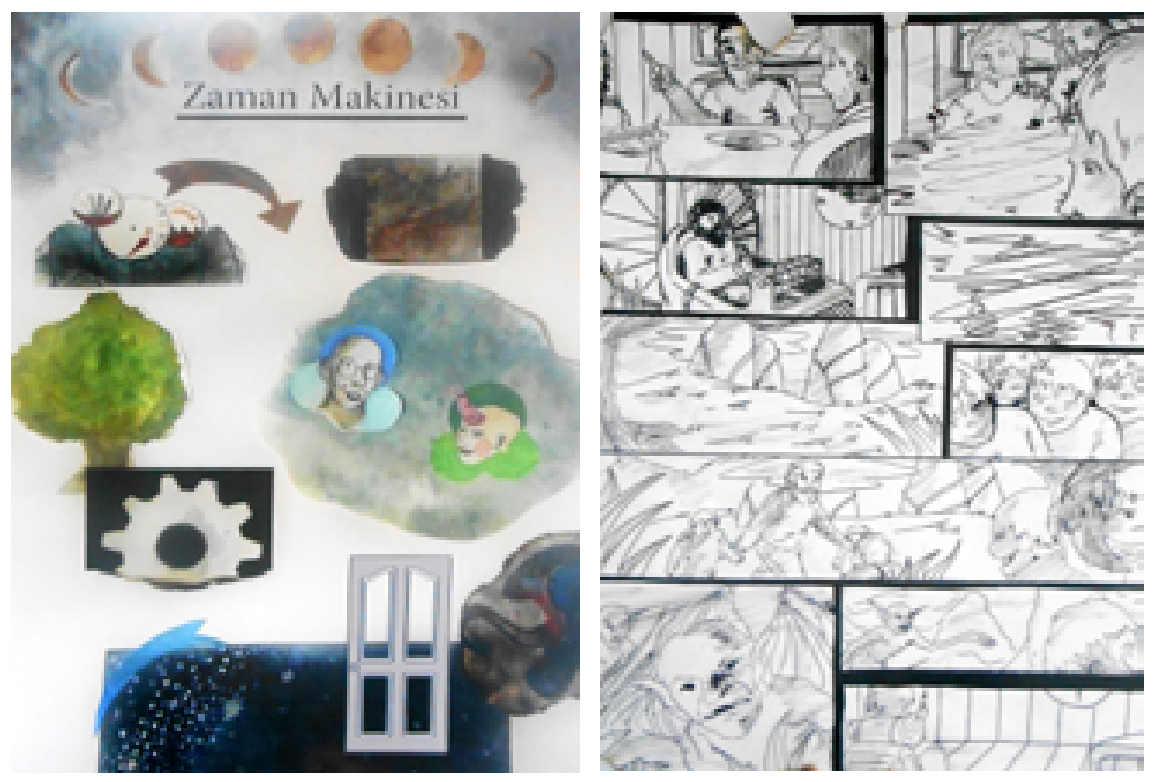

Resim 8: Gizem Güler, Öğrenci Çalışması

Resim 9: Ceyhun Yılmaz, Öğrenci Çalışması 


\section{Sonuç}

Desen dersi temel sanat eğitiminin önemli bir bileşenidir. Öğrenci, sanatsal fikirlerini hayata geçirerek sanatsal üretime dönüştürebilmek için bu teknik donanıma ihtiyaç duyar. Bu teknik donanımın sanat alanında gerçekleşen gelişim ve yeniliklere cevap verir nitelikte olması gereklidir. Yirminci yüzyıl ve sonrasında sanat alanında gerçekleşen akımlarla sanat, disiplinlerarası etkileşimin arttığı bir etkinliğe dönüşmüştür. Görsel sanatlar eğitiminin bir parçası olan desen eğitiminin de bu değişimden uzak kalması mümkün değildir. Ders program ve içeriğinin, bu doğrultuda gününün teknik olanaklarından yararlanan ve disiplinlerarası bir yaklaşımla oluşturulmasının olası faydaları şu şekildedir: Öğrenci desen dersinde çeşitli sanat akımlarının temellendiği fikirsel atmosferi deneyimleyecek, sanatsal algı ve üretiminde çağın gereklerine daha kolay uyum sağlayabilecektir. Bu doğrultuda desen dersi hem öğrencinin zevkle zaman geçireceği, hem de çağın dinamiklerine ayak uydurabilen bir süreç niteliği kazanacaktır. Desen adı verilen, görülenin çizgilerle yansıtıldığı dinamiğin, geleneksel anlayışa ek olarak, belki de geleneksel "çizgi" olgusunu aşarak teknoloji ve farklı disiplinlerin de katıldığı yeni bir yapıda tanımlanması, düzenlenmesi ve gerçekleştirilmesi temel sanat eğitimi için atılması gereken önemli bir adım olabilir.

Sanatsal üretimin başlangıç noktası insan zihnidir. Bir sanat eserinin kıvılcımı zihinde oluşur. Bu kıvılcım sanatçının hayal gücü ve sanat algısıyla büyüyüp şekillenerek sanatsal bir tasarıma dönüşür. Bu bağlamda hayal gücünün, sanatsal üretim sürecinin önemli bir noktasında olduğu söylenebilir. Bu durum sanatın söz konusu olduğu pek çok etkinlikte ortaklık gösterir. Sanatsal üretimin biçimi ve üretimde kullanılan araçlar noktasında, sanat dalları arasında bir tür biçimsel ayrışma gerçekleşir. Edebiyat gerek üretim gerekse tüketim süreçlerinde hayal gücünün etkin bir şekilde kullanıldığı bir sanat dalıdır. Örneğin, bir roman ya da hikaye, okuyucunun zihninde hayata bürünür. Bu noktada okuyucunun hayal gücü, okuduğu metnin gerçekleşme biçimine etki eder. Kullanılan bir becerinin gelişmeye açık olduğu fikrinden hareketle, edebiyat alanındaki roman ya da hikaye türünün hayal gücünü zenginleştiren bir etkinlik olduğu sonucuna varabiliriz.

Desen çalışmalarında genel bir ifadeyle bakılanı görmek, görüleni çizebilmek hedeflenmektedir. Dolayısıyla geleneksel bir anlayıştaki desen eğitiminde bir tür var olandan hareket söz konusudur. Görsel bir objenin bir zemin üzerine aktarımı teknik anlamda öğrenciye bazı kazanımlar sunsa da, böyle bir etkinlikte hayal gücü ve yaratıcılığın daha arka planda yer bulabileceğini söyleyebiliriz. Bu noktada disiplinlerarası bir yaklaşımla desen-edebiyat 
birlikteliği, sanatın vazgeçilmezi olan hayal gücü ve yaratıcılığın öğrencinin daha "emekleme" döneminde gündemine alınmasının önünü açacaktır. Desen dersi bu şekilde gördüğünü görsel dönüştürme noktasından, belki de bir adım öteye, okuduğunu görsele dönüştürme noktasına taşınarak yeni bir boyut kazanacaktır. Bu boyut öğrencinin hayal gücünün kullanımını daha ön plana çıkaran bir boyuttur.

Desen eğitiminde edebi metinlere yer verilmesi, sınıf içi kollektif bir çalışmayla öğrencilerin aynı hikayenin farklı bakış açılarından, farklı gerçekleşme biçimlerini görmelerini sağlayabilir. Bu şekilde sanat eğitiminin diğer önemli bir boyutu olan özgünlük fikrine dikkat çekilebilir. Bu doğrultuda öğrencinin sanatsal empati yeteneğinin gelişimine katkıda bulunulabilir. Disiplinlerarası bir etkileşimin arandığı-uygulandığı eğitimöğretim sürecinde ortak bir konuyu bireysel bir ifade biçimiyle aktarabilen öğrencinin, romanda konu edilen zaman, mekan ve çeşitli ilişkileri kendi bakışında nasıl alımladığı ortaya çıkmaktadır. Desen eğitiminde, öğrenciler derse yönelik malzemeyi kullanabilmeyi, görmeyi öğrenmeli, gördüğünü kağıt üzerine birebir aktarabilmeli, ardından nesneleri soyutlayabilmeli, düşüncelerini çizgileri ile ifade edebilmeli, sanat eserleri ile ilgili bilinçli kritik yapabilmeli, özgün çizgileri ile yaratıcı kompozisyonlara (tasarımlara) ulaşabilmelidir. İmgesel çalışmayı hedef alan bu projede, yeni bilgilerle donanan öğrencinin yaratıcı düşünce süreçleri desteklenmiş, farklı anlatım tekniklerini kullanabilme imkanı bularak kendine güveni artmıştır.

Ders sürecinde öğrenciler kendi fikirlerini özgürce ifade edebilmişler, yaratıcı çözümlerde bulunmuşlar, diğerarkadaşları ile birlikte gruplarhalindeçalışarak beyin fırtınası gerçekleştirmişler, aynı romanı çok farklı ve kendilerine ait tasarımlarla görselleştirmişler ve farklı teknikleri kullanabilmişlerdir. Yaratıcı düşüncenin harekete geçtiği süreçte, somut bilgiler değerlendirilirken yeni kompozisyonlara ulaşılabilmiştir. Gerçekleştirilen bu proje sonucunda, öğrencinin desen gücünü ortaya çıkaracak ve geliştirecek uygulamalara gidilmiştir. Desen dersinde, disiplinlerarası bir yaklaşımla edebiyat, sanat tarihi, sanatın felsefesi gibi konularında ele alındığı bir eğitim-öğretim süreci yaşanmıştır. Öğrenciler, farklı siyasi yapılanmaların, teknolojinin ya da hayal gücünün sanatın oluşum sürecinde nasıl yer ettiğini kavramışlardır. Öğrenciler, desen ile ilgili genel terminolojiyi öğrenerek derse yönelik farklı malzeme ve teknikleri kullanabilir hale gelmişlerdir.

Görsel-plastik, sessel, devinişsel, sözel, eylemsel alanların tümünde olması gerektiği gibi desen alanında da bütüncül bir yaklaşım ile disiplinlerarası bir eğitim anlayışı hedeflenmeli ve bu hedef doğrultusunda öğrencilerin çok yönlü gelişimlerinin destekleneceği eğitim programları hazırlanmalıdır. 


\section{Kaynakça}

Ak, S. A. (2003). Fotoğraf/Söz Kavuşması. Istanbul: Bileşim Yayınevi.

Altunay, A. (2004). Mekanik Sanattan Elektronik Sanata Geçiş ve Video Sanatı. Eskişehir: Anadolu Üniversitesi Yayınları; No: 1539, Iletişim Bilimleri Fakültesi Yayınları, No: 54.

Araz, G. (I8-24 Ekim 2009). “Yeni Dünya, Yeni Sanat”. Anadolu Üniversitesi, Güzel Sanatlar Fakültesi (Fine Arts \& Design Symposium) Uluslararası Katılımlı Güzel Sanatlar ve Tasarım Sempozyumu, Eskişehir.

Atakan, N. (1998). Arayışlar, Resimde ve Heykelde Alternatif Akımlar. İstanbul: Yapı Kredi Yayınları.

Aytaç, G. (2005). Edebiyat ve Medya. Ankara: Hece Yayınları.

Bingöl, P. M. ve Kayahan, Z. (27-28 Nisan 2015). "Desen Eğitiminde Birleşik Bir Program Önerisi”, 2. Sanat ve Tasarım Eğitimi Sempozyum ve Çalıstayı. Başkent Üniversitesi, Güzel Sanatlar Tasarım ve Mimarlık Fakültesi, Ankara.

Bingöl, P. M. ve Taşpınar, E. Ş. (20-25 Ekim 20/4). "Sanatın Dönüştürme Biçimleri Üzerine Bir Inceleme”, 58-65. Uluslararası Sanat ve Tasarım Kongresi, Dokuz Eylül Üniversitesi Güzel Sanatlar Fakültesi, Izmir.

Buğra, B. H. (2000). Cumhuriyet Döneminde Resim Edebiyat Ilişkisi. İstanbul: Ötüken Yayınları.

Erdal, G. G. (I8-24 Ekim 2009). “Disiplinlerarası Sanat Etkileşiminde 20. Yüzyılın ilk yarısında Resim ve Müzikte Ortak Kavramlar”, Anadolu Üniversitesi, Güzel Sanatlar Fakültesi (Fine Arts \& Design Symposium) Uluslararası Katılımlı Güzel Sanatlar ve Tasarım Sempozyumu, Eskişehir.

Graf, M. (2008). Genco Gülan: Kavramsal Renkler. Çev: Bengi Gün ve diğerleri. Istanbul:Galeri Perform Yayınları, Sanat No:I.

Heptunalı, Ö. (2007). “Günümüzde Plastik Sanatlarda Yeni Sanat Yaklaşımları ve Bu Yaklaşımların Sanat Eğitimindeki Yeri”, Yüksek Lisans Tezi, Dokuz Eylül Üniversitesi Eğitim Bilimleri Enstitüsü Güzel Sanatlar Eğitimi Anabilim Dalı Resim-Iş Öğretmenliği Programı, İzmir.

Jones, C. (2009). Interdisciplinary Approach - Advantages, Disadvantages, and the Future Benefits of Interdisciplinary Studies, ESSAI: Vol. 7, Article 26.

Kayahan, Z. (20I0). İlköğretim I. Kademe 5. Sınıf Görsel Sanatlar Eğitimi Dersinde Hikaye Anlatım Yönteminin Yaratıcılığa Etkileri, Yüksek Lisans Tezi, Gazi Üniversitesi Eğitim Bilimleri Enstitüsü Güzel Sanatlar Eğitimi Anabilim Dalı Resim-Iş Öğretmenliği Bilim Dalı, Ankara. 
Lynton, N. (2004). Modern Sanatın Öyküsü. 3. Basım. İstanbul: Remzi Kitabevi.

Meyers, J. (1975). Painting and The Novel.U.S.A: Manchester University Press, Barnes\&Noble Books.

Pekmezci, H. (08-IO Mayıs 2002). “Eğitim-Sanat Eğitimi-Nitelikli Insan Eğitimi”. Sanat Eğitimi Sempozyumu, , G. Ü. Gazi Eğitim Fakültesi “Türkiye’de Sanat Eğitimi ve Öğretmen Yetiştirme", Ankara.

Sözen, N. H. (2010). “Sanatta Disiplinlerarası Bir Yaklaşım: Enstalasyon Sanatı ve Genco Gülan Örneklemi”. Gazi Üniversitesi Güzel Sanatlar Fakültesi Sanat ve Tasarım Dergisi, 6. Sayı, Aralık.

Suraco, T. L. (2006). An Interdisciplinary Approach in The Art Education Curriculum, A Thesis Submitted in Partial Fulfillment of the Requirements for the Degree of Master of Art Education in the College of Arts and Sciences Georgia State University.

Türkdoğan, T. (20/4). Sanat Kültür Politika-Modernizm Sonrası Tartışmalar. I. Basım. Ankara: Nobel Yayınları.

Ünser, O. (2004). Kelimelerden Görüntüye. İstanbul:Es Yayınları.

Yamaner, G. (2007). Postmodernizm ve Sanat.Ankara: Algıyayınları.

Yılmaz, M. (2005). Modernizmden Postmodernizme Sanat. I. Baskı. Ankara: Ütopya Yayınevi.

\section{Internet Kaynakları}

Internet: Edebiyat ve Resim. (I4 Mart 2013).

Web:http://edebiyatkalemi.blogspot.com.tr/search/label/Edebiyat\%20ve\%20Resim30 Ekim 2015'de alınmıştır.

Internet: Metamorphosis (20I2 film). (2I May 20I5).

Web:https://en.wikipedia.org/wiki/Metamorphosis_(2012_film)30 Ekim 2015'de alınmıştır.

Internet: Roman Resme Dönüştü.(20 Aralık 20/3).

Web:http://www.haberler.com/roman-resme-donustu-5447598-haberi- 30 Ekim 2015'de alınmıştır.

Internet: The Novel as an Art Form (Museum of Modern Art in Warsaw \& Cricoteka). (October, 2013). 
Web:http://www.thebooklovers.info/The-Novel-as-an-Art-Form-Museum-of-Modern-Artin-Warsaw-Cricoteka 30 Ekim 2015'de alınmıştır.

\section{Görsel Kaynakları}

Resim I-2: http://www.thebooklovers.info/THE-BOOK-LOVERS

Resim 3-4-5-6-7-8-9: Mehtap Pazarlıŏlu Bingöl Desen Atölye Öğrenci Çalışmaları Arşivi. 
